\title{
POPULAR CATHOLIC EDUCATION IN VENEZUELA
}

ABSTRACT To a Polish reader, Venezuela is far away, despite the globalized world in which we live. The same is true in reverse: few Venezuelans know where to locate Poland on a map of Europe. However that fact does not prevent us from taking this opportunity to - by using the cont of this volume - build bridges between the two countries. There can be several pillars upon which to build, the most important of which is the common Catholic religious culture that we share. A historical tour will help explain the importance of Catholic education provided in the educational institutions dependent on the Catholic Church.

KEY WORDS Catholic education, Venezuela.

П a Polish reader, Venezuela is far away, despite the globalized world in which we live. The same is true in reverse: few Venezuelans know where to locate Poland on a map of Europe. However that fact does not prevent us from taking this opportunity to - by using the cont of this volume - build bridges between the two countries. There can be several pillars upon which to build, the most important of which is the common Catholic religious culture that we share. A historical tour will help explain the importance of Catholic education provided in the educational institutions dependent on the Catholic Church - a culture that is not common yet, as it has been lived differently depending on the historical circumstances that each country has experienced. The current features of Catholicism in Venezuela could be characterized as follows: traditional religiosity rather superficial, devotion for church representatives, devotion to saints and the Virgin Mary, certainly not without some contamination from superstitious practi- 
ces. They are a few people who want to learn more about their Catholic faith, within an increasingly pluralistic society in which agnosticism is still a minority.

The reasons that support these features have to do with the way the Catholic faith is taught: most children receive religious instruction for their First Communion, and a small group of them also receive Confirmation catechesis, but their religious knowledge stops there, as is the practice. There are mothers who teach their children to pray, but if they do not set a good example at home, faith decays and becomes routine. Attendance at the Sunday Mass does not exceed $10 \%$ to $15 \%$ of the faithful in most parishes. Hence the importance of Catholic education taught in educational institutions dependent on the Catholic Church. A historical tour will help explain the problem as is now appears.

\section{REVIEW OF THE EDUCATION SYSTEM: NINETEENTH CENTURY}

The characteristics of the education system in Venezuela - hence also of Catholic education - have much to do with the history of the country in the last two centuries, after gaining independence from Spain in 1811. Simon Bolivar attached much importance to education in his decrees, but national governments did not worry about it. Once discrimination by social class and color was eliminated from university admission policy, he decreed the establishment of numerous primary schools and enacted a House of Education as part of the moral power, which did not exist. A sentence used by Bolivar expresses their appreciation of good education: Nations march to the end of their greatness with the pace with which they manage their education. But he was ignored: illiteracy was widespread for much of the nineteenth century. In 1839 only 215 primary schools functioned in the population centers of greatest number of inhabitants. Only one in 114 children received primary education in the country. At the level of secondary schools there were 12 for men and just one for girls at the middle of nineteenth century. There were two universities, one in Caracas and the other one in Merida.

Simon Rodriguez, Bolivar's teacher, tried through his activity and writings - to provide education to everyone, not just for white people, and assigned to it a practical purpose. He taught his students to think on their own and also to think about others: Teach children to be inquisitive, to ask why they're told to do something. Teach them to obey reason, not authority, as limited people follow the custom as the stupid $d o{ }^{1}$

In the second half of the nineteenth century, the most important president, Antonio Guzmán Blanco, challenged the Church - a move which was motivated by his secular character and enlightened thought; he also feared the Church as force of religious power opposite to his megalomania. He refused, even in the spiritual order, to acknowledge a superior authority to his own, but very reluctantly had to negotiate with the Church. One of the features of his most memorable and controversial government would be his confrontation with the Catholic Church, which held differences that led him to take

S. Rodríguez, Obras completas, Tomo 2, Caracas 1975, p. 27. 
repressive measures against its representatives, which led to a series of actions that sought the definitive separation of Church and State, such as the creation of the Civil Registry, the confiscation of Church property and ultimately an attempt to separate the Venezuelan Church from the Vatican and institute himself as an independent and supreme leader of the Church. ${ }^{2}$ Guzmán Blanco decided to close seminars, cloisters, and churches, and transfer religious teaching to secular universities. He also stripped the Church of its influence and most of its property. But in the field of education, Guzmán Blanco has excelled in the history of Venezuela for having enacted the Public Education Act of 1870, drafted by Minister Martin Joseph Sanabria, providing free and compulsory elementary education. It was an important decree, exemplary at the time, since Great Britain was the only country to establish compulsory primary education in that same year and Germany followed suit only in 1889. Thanks to this decree the number of schools increased from 300 in 1870 to 1,957 in 1885 and the number of students nationwide went from 10,000 to 99,466. The establishment of the State as the body responsible for providing education was also of great importance for the country's future. The Church lost its influence in education and in society in general and had to accept the secular nature of the State. This separation of Church and State is a feature now common for all Western countries.

\section{THE TWENTIETH CENTURY}

Dictator Juan Vicente Gómez (1908-1935) allowed the return of religious congregations who had been expelled by Guzmán Blanco. A Christian Brothers School was founded in Barquisimeto in 1913, another one in Puerto Cabello in 1921; new ones were set up in Caracas and San Cristóbal in 1922 and in Valencia in 1925. Jesuit highschools were founded in Caracas (San Ignacio 1923) and in Mérida (San José 1927). Marist Brothers founded the highschool of Our Lady of Chiquinquirá in Maracaibo in 1925. Women's congregations also founded several schools for girls during that period: the Dominican Santa Rosa de Lima in Caracas (1928) Calabozo, and Ciudad Bolivar; the Sisters of Consolation founded four colleges during that period; the Salesian Sisters founded their educational institutions in Mérida, San Cristobal, and Los Teques. ${ }^{3}$

At the end of Gomez' dictatorship there were 50 schools and 17 religious congregations in the country largely devoted to education. San Ignacio high-school would educate important Venezuelan personalities in the political and economic spheres. There was here a confluence of interests between the Church and the country's social elites, educated at Catholic schools. Through education the Church was changing the anticlerical environment and secularist dominant thought, which reappeared later when

2 'Antonio Guzmán Blanco', Wikipedia, at <http://es.wikipedia.org/wiki/Antonio_Gum\%C3\%A1n Blanco>, 30 September 2012.

3 CERPE, La educación católica en Venezuela (1889-1986), Caracas 1986. 
Democratic Action took the reins of government from 1945 on. Religious educators came from abroad, especially from Spain, marking the Venezuelan Church significantly: most of the clergy were of foreign origin and they influenced natives, although after an increase vocations among diocesan priesthood foreign influence reduced and is now hardly noticeable. General education declined however, because of government restricted resources. Gomez for instance reduced education's share from $8 \%$ to $5 \%$ of the national budget. The number of students was about the same when Gómez ruled as it has been 50 years earlier in the presidency of Guzmán Blanco. The government was hardly interested in extending education to all the citizens, because it is easier for dictatorships to flourish when the majority is ignorant. It is also true however that Gomez was able to surround himself with the most talented people in all areas, including education. In those years, he established an educational system based on the common liberal positivist spirit among intellectuals, which worked well, although was primarily aimed at the elites.

In the second decade of the twentieth century, oil extraction continued in abundance and that changed the conditions in the country. It had been an economy based on agriculture (coffee, cocoa) and therefore poor, but then became an oil-based economy - a fact that greatly influenced Venezuela for almost a century. Since then the economy has been based on service or tertiary sectors, with easy access to productive consumption; particularly, it has been an economy ruled by the state with little private involvement, dependent on the government. The population is concentrated in cities. In 1920 urban population was $26 \%$ - it is currently over $85 \%$. All this shapes Venezuelans' style of life and work, and leaves its mark on education.

While Gomez had not bothered to extend education, but only supported elite education, the governments that followed after his death (December 1935), especially the Democratic Action Party have attached great importance to popular education. Educational philosophy seeks the modernization of society through education of all. Education is directed and controlled by the state, which allows for the private sector, but is monitored closely. It is what is referred to as the Teaching State. This relationship between private education and the state has experienced periods of conflict, such as that which occurred in June 1946 and has served to reinforce the barely a few months old Venezuelan Association of Catholic Education, AVEC.

We can say that the "democratic humanism", a term that summarizes the educational philosophy of the Democratic Action government, was a breakthrough. That humanism embraced various aspects: mass education as opposed to only the elite education, free education at all levels and compulsory at the primary level, vocational training and finally: the importance attached to democracy and to the educational State, which also meant teacher training only by State. In the implementation of this philosophy Democratic Action was sometimes sectarian and collided with the private Catholic education, which came from a political and social conservative class. The Church advocated freedom of education and the ability to train teachers in institutions run by it. Religious educators from Europe conceived education as the great instrument to create intellectual and ethical leadership and were able to propose a social project for 
Venezuela. Thus the Catholic unions and the Social Christian Party COPEI, founded by Jesuit Father Manuel Aguirre, were born, which would later play a pivotal political role in the person of President Rafael Caldera.

In 1959 first agreements between the Ministry of Education, private foundations, and the Church were established. High and pre-vocational schools were founded, aimed at popular sectors students in grades four through six. This initiative led in 1967 to form the Association for Popular Education (APEP), whose activities were subsequently extended to the training of teachers and the training of technicians. ${ }^{4}$

\section{THE VENEZUELAN ASSOCIATION OF CATHOLIC EDUCATION, AVEC}

Catholic schools, which were already several dozen in 1945, came together in partnership, driven by the American Congress of Catholic Education, which met in Bogota in June 1945. The founder of the Venezuelan Association of Catholic Education AVEC was Carlos Guillermo Plaza, a Jesuit who also founded the Catholic University Andres Bello UCAB in 1953, proposed by Venezuelan Episcopate. Catholic education contributed to the modernization of the country, along with democratic humanism of the Democratic Action Party, but from a different philosophical approach. Its vision was of man and society as part of the human being made in the image of God, and of the society as needed of strong social reforms, taught by Catholic social teaching. These reforms can only be realized through governments and its public servants, which do not try to take advantage or remain in power. This has been the core of the ongoing criticism directed by the Church at politics - a criticism often rejected by those who call themselves public servants.

Carlos Guillermo Plaza SJ (1907-1975) was a Venezuelan of wide culture and ahead of his times due to his ideas on the human condition and his founder capacity. No figure in the twentieth century excelled more than him in the defense of religious education and private educational institutions. It was an exceptionally brilliant man who made valuable contributions to the nation on education. When the project of a possible Venezuela was being discussed along with the ideal of the citizen, Father Plaza presented to the nation his considerations in the light of the Church's teachings, so that the contemporary government would take them into account.

The Democratic Action Ministry of Education issued a decree on May 30th, 1946, regulating final exams, grades, and promotion requirements for students. This decree was discriminatory to private schools in an effort to control or even punish them. Students and teachers went out on demonstrations in the streets of Caracas and the government withdrew the decree. Catholic education was strengthened and the government recognized it as its partner.

4 N. Rodríguez, 'Las cuatro décadas de la democracia' in Historia de la Educación en Venezuela. 6 ensayos, Caracas 2011. 
Low wages have consistently been a fixed feature that marked the society's and government's approach to teachers. Teachers have hardly been able to cover their basic needs and many times in the past their wages were lower than those of a secretary or a janitor. Under these conditions it is not surprising that teaching vocation does not receive high social esteem. As Mario Briceño says in his novel Los Riberas (cited by L. Carvajal): Teachers are the silent heroes who are praised by some people but it does not matter to the city management. Schoolteachers are but sad citizens dedicated to protect their miserable little salary. Prieto Figueroa and his partisans were those who gave the unionist a consciousness and taught them to fight for their rights, especially for a better salary.

The relationship between the Church and the successive governments of Venezuela has never been easy in spite of the Catholic roots of the majority of those governments. As said before the military and the strong governments in the nineteenth century cared little for education in general. Guzman Blanco persecuted the Church and tried to cause the Venezuelan Church to secede from Rome. In the twentieth century however, the two governments that treated the Catholic education best were the dictatorships: Juan Vicente Gómez's and Marcos Pérez Jiménez's ones. The Democratic Action Party, which ruled from 1945 to 1948 , and then for 30 years out of the 40 years of democracy had strong problems with Catholic education in the forties, but then learned to reach an understanding, to the point of signing an agreement in 1990 that allowed the economically-challenged Catholic institutions serving the poor to be financially supported by the state.

The forty years of democracy following Perez Jimenez dictatorship between 1958 and 1998 saw an improved spread of education and a qualitative improvement within the first 20 years of that period. There has been a breakthrough in the professional status of teachers, in their levels of consciousness, in the modernization of education with correspondingly greater use of technology. ${ }^{5}$ While in 1948 only 108 out of 1,000 Venezuelans were educated at the various levels of education, and in 1957 that number was 118 , the figure climbed in the reporting period to reach 301 for every 1,000 thousand. Throughout the country's independent history until 1961, the military spending surpassed the educational one. Only from that year on was the expenditure on education greater than that on weapons, which means an improvement in civil facilities. The current government has reversed that trend and spends far more money on weapons and military training than on teachers and schools.

One of the main achievements of the democratic period was the teaching of the democratic spirit, not only or even primarily as a result of schooling, but as practical exemplification. The alternation of power every five years of Democratic Action and COPEI and in the last five years of a new party, Convergence, and the election of deputies, governors and mayors made a way to consider practice of politics in most Venezuelans. The separation of the legislative, executive and judicial power, not always clear, but acceptable, reinforced the exercise of democracy. Nevertheless, democracy

5 L. Carvajal, La educación venezolana del XIX al XXI, Caracas 2010, p. 154. 
failed in the care of the poor and in the effort to reduce social inequalities, which favored the accession to power of the current regime, far removed from the democratic legitimacy.

Regarding wages and salaries, the Minister of Education Professor Antonio Luis Cardenas handled the teachers issue magnificently: in 1995 they earned three times the national minimum wage, something unheard of until then and not maintained afterwards.

The current government under President Chávez has dismantled democratic institutions which were critical to his project in maintaining power, imitating Fidel Castro. In the educational aspect Missions and Education Act passed in 2009 constituted the fundamental pillars of education to support his totalitarian claim. Missions, operating for the inclusion of the poor in areas such as health and education had a political aim, as confessed by the President himself, to help win his reelection in 2006. Educational missions consist of establishing a parallel education system with the intention of making the official system weak, which has not yielded to their hegemonic designs. This has occurred especially at higher institutes which have mushroomed seeking top level political campaigning rather than vocational training with well trained graduates intended to replace professional cadres and technicians working in the public service. The quality of the missions leaves much to be desired and consistency is weak, because they respond to the political establishment and then are neglected by the government.

The Education Act, passed in August 2009, aims to lay the foundations for the creation of a socialist state, in contradiction to the existing 1999 Constitution, which in its Article 102 stipulates that the State cannot ignore ownership rights inherent to the person, including the freedom of thought and education. The State can and should regulate, provide guidelines, and context, but the right is inherent to the individual and the State plays a role only to support and fulfill the primary right of the individual, not to replace it. Regarding the orientation of the law, the main features that characterize it are ambiguousness, statist ideological character, punitive inclination, ignorance of teacher and school, suspicion against freedom. The law is general, so that there were additional 20 laws and regulations introduced to implement it. The LOE is centered in an exclusivist Teaching State, solely responsible for the overall direction of education and the management of educational institutions. Directed to impose an out-of-date ideology, which failed worldwide, dictatorial, inclined to punishment, as evidenced by the final provisions of Title VII, which maintain the same 24 motives to sanctioning teachers, school students and institutions existing in the 1980 law and gives no encouragement. The new Education law seems to curtail autonomy of higher education institutions through the absurdity of election mechanisms and allocation of student quota, which incidentally have not been applied to higher education institutions founded by the government these years.

It does not appear in the new law a provision allowing the State to subsidize private schools that serve students from poor sectors. This omission expresses the will of the officer on duty to jeopardize State contribution to institutions like Fe y Alegría, which have earned national and international recognition for their work with poor. Previous 
education law envisaged the provision of teaching positions through competition. This mechanism has been ignored by current government, which has placed political stalwarts in positions of teachers and educational leaders.

\section{AVEC TODAY}

We have seen how Catholic schools were grouped into the AVEC in 1945 to help form a Catholic initiative for the provision of better education, within the guidelines of the State Constitution and in collaboration with formal education. Its excellent historical fruits are visible and also its high valuation and current demand. In AVEC there are two types of centers that differ in the funding method: 1) Parents pay the full cost of education. 2) Family pays a small part and government pays the difference. Both modalities are nonprofit and need sufficient income to stay open and maintain quality. $76 \%$ of AVEC education serves low-income families, a figure that stands out in Latin America. We are not talking only of Fe y Alegria, which serves a third of the more than 500,000 recipients of education funded by the Venezuelan agreement, the remaining two thirds are studying in schools, parishes, congregations of laity or religious tradition in popular education here and around the world, including La Salle, Salesian and Franciscan families, Marist, Escuelas Pias, Dominicans, Carmelites, Augustinians, sisters of the poor and others. ${ }^{6}$

AVEC has currently a relationship with the government that can be described as tense, because subsidies do not arrive on time and are lower than those paid to qualified teachers. The Association includes both Catholic schools aided by the grant agreement by the State ( 623 schools), as Catholic schools not subsidized by the state for not being deficient (185 schools).

AVEC serves in 2010-2011 to 508,708 students, especially in elementary and middle schools, 388,820 of which belong to subsidized schools and 119,888 to unsubsidized. 31,910 teachers work in the AVEC benefited schools, 23,260 of which are women and 8,650 men. The meaning of the State-AVEC Convention is to ensure rights of children and young people to quality education, although not coming from resourceful homes.

\section{FE Y ALEGRÍA}

The Catholic University Andres Bello, UCAB (1953), was founded during Marcos Perez Jimenez' (1952-1958) dictatorship but the most important fact for the issue at hand is the foundation of Fe y Alegría in 1955 by P. José María Vélaz, Chile-born Jesuit of Spanish descent. Fr. Vélaz was busy before as spiritual father at recently founded Catholic University, giving attention to students of the Marian Congregation. He invited them to visit Caracas' poor neighborhoods, searching to teach Catechism.

6 L. Ugalde, ‘Convenio para la buena educación', El Nacional, 9 February 2012. 
But he quickly noted, and with him his students, that primary need was helping them to overcome their situation of origin through education. A neighborhood worker, Abraham Reyes, was the first volunteer who donated his house to establish the first school of Fe y Alegría. In an original document he wrote, Vélaz says: Fe y Alegria is a work or rather a movement that grows and evolves under Christian inspiration of love to the destitute, not caring them and protecting them but awakening in them the wonderful spring asleep in their own determination, their intimate self, their true freedom. This is the least paternalistic institution. Fe y Alegría covers primary, secondary, normal education, agricultural and technical schools, trade and services, higher education (five colleges), job training centers and schools radio. One slogan that reflects its founding spirit says: "Faith and Happiness begins where asphalt ends." It covers currently 165 schools in Venezuela, with a total of 290,988 participants in all educational programs mentioned above. They are altogether 13,841 educational, administrative personnel and laborers working in Fe y Alegría in Venezuela.

Fr. Vélaz spread their enthusiasm to countless diverse religious congregations and many lay people who contributed with their work, talent and money. Foundation in Venezuela was followed by Ecuador (1964), Panama (1965), Peru and Bolivia (1966), and Colombia, El Salvador, Nicaragua and Guatemala, Argentina, Honduras, Paraguay, Brazil, Dominican Republic, Chile, Haiti and Uruguay, following a continental project to reach all Latin American countries. It's also based in Spain and Italy (2002), to cater mainly for children's needs of American immigrants. In 2008 began Fe y Alegría in Africa, notably in Chad, which already runs 10 schools.

A great educator, Venezuelan Simón Rodríguez, who was a teacher and friend of Simon Bolivar, exclaimed:

Ask, on behalf of the poor, whether they are entitled to know. If they are taught (...) and why. Who teaches (...) and how. If the person is required to comply with this obligation to teach, because teaching must not be halves on. Things have not to be half done but only while they are been done.

This was dominant concern of Father José María Vélaz in founding Fe y Alegría: that poor did not have a poor education, but the best. He devoted to this purpose his enormous talent and extraordinary energy.

Fe y Alegría has undertaken to promote six commitments for education:

\section{Access, process and outcomes in terms of equity}

Access to the educational system. All children should have opportunities to access school education. State must ensure sufficient places and physical accessibility (proximity to a center), curriculum (proposals relevant to learners) and economic (free education mandatory).

The educational process. Once achieved access to education, it takes attention and resources to continue learning and successfully overcoming stages. This implies additional support and resources for those who need more, the best educators for the most

S. Rodríguez, Obras completas, p. 29. 
deprived pupils, school calendars appropriate to the various realities, language learning, etc.

Results. The differences in results must not reproduce inequalities of origin or condition future options. Education should promote skills that enable students to participate in their social environments and develop their life projects, according to their talents, interests and motivations.

\section{Comprehensive and inclusive educational quality}

Quality education is the way promoting person's development in all dimensions, which values its individual uniqueness and its social membership by promoting socio-cultural construction and learning of knowledge, attitudes and skills, that enables them to improve the quality of personal life and community, incorporating people to country life and involving them in the construction of a more just society.

In each country, particular approach to quality must come from broad social agreement on the aims and objectives of education in general and of each stage, considering both the man's right to freedom and full development of his capacities, and the demands of society in terms of training for citizenship, work, scientific and technological progress and cultural creation. In this framework, factors of quality of education can be structured operationally around three axes: epistemological, pedagogical and administrative organization.

a) Epistemological. Socially valid knowledge: cognitive skills needed skills, values and attitudes to develop in students, as well as forms of knowledge construction.

b) Teaching. Characteristics of students and how they learn, characteristics and roles of educators, how processes and educational settings are organized to achieve the desired results.

c) Organizational and administrative. The structure of the level or stage, the extension of the school term and daily time in days, financial and material resources, the operation of the centers, community involvement and the role of management teams.

\section{Lifelong learning}

Educational policy should cover those forms of education that best serve, in various forms and stages, to promote personal development, education and training of people in a country. When we talk about lifelong learning we mean an integrated and articulated education system that provides opportunities for education, formal and informal, to the length and breadth of life that transcends educational institutions and link education with production systems and employment, culture, social networks, etc. To ensure education system interface with other systems, it is necessary to integrate different social actors in the formulation and implementation of education policies.

\section{Strengthening the teaching profession}

To improve teacher quality preparation must be strengthened, which involves improving working and living conditions of teachers, their training and performan- 
ce. On the teaching profession high expectations converge with little social value. In some countries, teachers have gained rights and better payment, in other low wages predominate, empiricism and the union struggle. It is necessary for governments and society to become aware of the enormous responsibility of educators and estimate them accordingly.

\section{Sufficient funding}

While funding for education has been increasing in all countries of the region, has not yet allocated sufficient resources to address the right to a free, quality education. It is far from the $6 \%$ of national budget that developed countries invest. Huge differences between countries in the budgets reveal which priority is given to education by governments. In several cases, external debt service exceeds the national budget sector. Insufficient budgets summed up to deficiencies in resources management. However, the increased inefficiency of public education spending is related to the high costs of school failure.

None Latin American country can achieve sustainable development without undertaking a strong investment in education. Moreover, improving the quality and educational equity implies a significant increase in public spending.

\section{Education Management to enhance equity and quality}

Educational reforms have placed special emphasis on decentralization of education systems as a formula, while achieving greater efficiency in resource investment, facilitate autonomous management of the centers, help families to become more involved in educating their children, teachers to work with greater autonomy and effectiveness and local authorities to better manage resources. In most cases, the failure of policies has not been in their objectives, which remain valid and desirable. What has failed is its implementation, where have prevailed views and interests of administrative, financial and political power over pedagogical aspects.

Decentralizing administration, both at regional level and in the schools, opens the possibility of innovation in the service of equity and quality. It is therefore necessary that school autonomy is accompanied by a set of conditions that are sufficient resources to develop the autonomy granted, assuming leadership from management, democratic management of schools, greater participation by both part of teachers and parents' family, the dismantling of the state bureaucracy.

\section{CONCLUSION}

Education is a noble task of all social agents and in particular of parents. Among the educational institutions in Venezuela the Catholic Church plays an important role together with the State and through its long history has earned a highly respected social position. This is currently not perceived favorably by the country rulers. They see the Church as a busybody, according to the stormy history as laid out above in this paper 
and the particular inclinations of those who currently govern the country. Nevertheless population appreciates the educational work of the Catholic Church greatly and Catholic campuses are sought after and preferred to others.

After 40 years of strained relations between Church and State, it acknowledged in 1990 the educational work of Faith and Joy (Fe y Alegría), and provided public funds to help the AVEC (to which Faith and Joy belongs) to support schools with strong educational budget deficits, devoted to the poorest sectors. Other Latin American countries, the first of which was Bolivia much poorer than Venezuela assumed the costs and strongly supported Fe y Alegría. The current situation of tension between government and the Church is probably transient and will not lead to the elimination of private education as was the case in Cuba 53 years ago. The present times of globalization, of the opening up of minds and borders, and of global economic interests are not favorable for dictatorships anywhere.

\section{REFERENCES}

'Antonio Guzmán Blanco', Wikipedia, at <http://es.wikipedia.org/wiki/Antonio_Gum\%C3\% A1n Blanco >, 30 September 2012.

Carvajal L., La educación venezolana del XIX al XXI, Caracas 2010.

CERPE, La educación católica en Venezuela (1889-1986), Caracas 1986.

Rodríguez N., 'Las cuatro décadas de la democracia' in Historia de la Educación en Venezuela. 6 ensayos, Caracas 2011.

Rodríguez S., Obras completas, Tomo 2, Caracas 1975.

Ugalde L., 'Convenio para la buena educación', El Nacional, 9 February 2012.

F. Javier DUPLÁ SJ, Bachelor of Arts in Education; Universidad Católica Andrés Bello, Caracas; Lecturer, Researcher; Last published article: "Propuestas educativas para transformar el país", Revista SIC 746 (July 2012). 